\title{
ASSESSMENT OF TEMPOROMANDIBULAR DYSFUNCTION AND MANDIBULAR FUNCTIONAL IMPAIRMENT IN DENTISTRY ACADEMICS
}

\author{
Élcio Alves Guimarães¹, Tathiane Tavares Goulart², Kelly Duarte Lima Makhoul³, Lucas Resende Sousa4 ${ }^{4}$, Paulo Cézar \\ Simamoto Junior ${ }^{5}$, Gilmar da Cunha Sousa ${ }^{6}$, Alfredo Júlio Fernandes Neto ${ }^{5}$
}

\begin{abstract}
Introduction: Temporomandibular dysfunction (TMD) is a collective term adding up the entire problems related to temporomandibular joint (TMJ) and the mandibular functional impairment is one of the symptoms of TMD. It is known that the posture influences the onset of TMD, thus, as in the appearance of mandibular functional impairment. Dentists remain in inadequate positions during their workday, thus presenting an important risk factor for the onset of TMD. Objective: To classify temporomandibular dysfunction and mandibular functional impairment in undergraduates of the 8th period of the Dentistry course in the "Centro Universitário do Triângulo-UNITRI", in Uberlândia, MG, Brazil. Methodology: This is a cross-sectional, practical, exploratory with a quantitative approach, epidemiological study carried out through application of two questionnaires: Mandibular Functional Impairment Index (MFIQ) and Clinical Dysfunction Index (IDCCM or Helkimo Index). Results: The results found in the present study showed a higher prevalence of moderate TMD (70,83\%), followed by mild TMD (16.67\%) and severe TMD (12,50\%) and all participants were classified with mandibular functional impairment of low severity. Conclusion: The results of this research showed a high prevalence of moderate TMD in dentistry students and that there is no correlation between TMD and mandibular functional impairment. It was observed that many students had pain in the neck and/or shoulder.
\end{abstract}

Keywords: Mandibular functional impairment; MFIQ; Helkimo Index; IDCCM; Temporomandibular dysfunction; Dentists.

\section{INTRODUCTION}

Considered one of the elements of the stomatognathic system, the temporomandibular joint (TMJ) constitutes an important link between the mandible (an odd bone in which the lower teeth are implanted) and the temporal bone that is even and forms the skull. ${ }^{(1)}$ It is capable of performing complex movements such as mastication, swallowing, phonation and posture. This system depends on the function, health and stability of the joint to function properly..$^{(2)}$

According to Pachioni et al., the temporomandibular dysfunction (TMD) is a collective term adding up all the problems related to TMJ, which affects the associated structures that involve the chewing muscles. ${ }^{(3)}$ The characteristic symptoms are: muscle and/or joint pain, palpation pain, joint noises, crackling or popping when opening and closing the mouth, otalgia, tinnitus, vertigo, facial pain or headache, dislocations and limited mandibular function. ${ }^{(1,4)}$ Limitation of mandibular movements in the TMD group particularly may be due to both the jaw muscles and the joint structures, and TMJ pain may be an additional cause for limiting movement. ${ }^{(5)}$
The TMJ is anatomically and kinesiologically associated with adjacent and spinal joints, and because it is vulnerable to intrinsic and extrinsic changes, it may be affected by posture. ${ }^{(6)}$ According to the study performed by Souza in 2010 about posture and TMD, the stomatognathic system integrates the musculoskeletal system and its disorders decompose the postural harmony, as well as the postural deviations unbalance the stomatognathic system. ${ }^{(7)}$

Schaefer ${ }^{(2)}$ Defines posture as the relative disposition of the body at a given moment, and the correct position must be when the corporeal joints are in less stress. Zenkner et al., in their study on the stomatognathic system, posture and body balance in 2010, report that body posture is fundamental for several daily tasks, and the alignment of body posture is established by musculoskeletal structures that interact with themselves for a lifetime according to their requests. Thus, a bad posture generates several health damages, often irreversible, and can cause imbalances and falls, pains in various parts of the body, food problems and other disorders. ${ }^{(8)}$ 
Schaefer ${ }^{(2)}$ reports that there is an anatomical and biomechanical relationship between the head and the shoulder girdle with the stomatognathic system. This theory is supported by physics, which for the weight of the skull and keeping the head aligned, it is necessary to balance the muscular forces before and after the cervical spine. Zenkner et al., states that global body posture interferes with the position of the head, which in turn is directly responsible for the posture of the mandible, but the inverse relationship may occur, with dysfunction in the stomatognathic system leading to changes in body posture. ${ }^{(8)}$

Souza ${ }^{(7)}$ in a study about posture and temporomandibular dysfunction states that the skull and mandible have nerve connections to the cervical region. Therefore, an originally cervical pain may be referred to the face or a TMD can lead to cervical disorders. Thus, it has been postulated that the balance relationship between skull, mandible and cervical spine is of fundamental importance for the maintenance of the functionality of the craniomandibular system. ${ }^{(9)}$

Epidemiological studies of the last sixty years show that from $50 \%$ to $60 \%$ of the general population, without prevalence of age, gender and color, present some signs of masticatory disorder, with only $10 \%$ showing significant symptoms that lead to since it has a varied symptomatology and often does not present clinical signs, making it difficult to diagnose, investigate and treat disorders of the TMJ.(10) Siqueira et al., in their study about musculoskeletal pain in dental students, in 2010, affirmed that $60 \%$ of dentists who admit feeling pain after work and $15,5 \%$ confirm that they have acquired the problem during their professional practice. The most affected regions were neck, shoulder and lumbar spine. ${ }^{(11)}$ Ferreira et al., in 2012, affirmed that $26 \%$ of the 739 university students evaluated (18 to 25 years old) had symptoms of TMD. However, when these same students were clinically examined, it was observed that $76 \%$ had some sign related to TMD, making evident the importance of the clinical evaluation in the diagnosis. ${ }^{(12)}$

Dentists, in the exercise of their profession, permanently use the upper limbs, especially the hands and, in most cases, with repetitiveness of the same movement, with prolonged effort and maintenance of the posture that are not always the correct ones. ${ }^{(13)}$ Dentistry has been considered a "stressful" profession and is frequently associated with health problems, both physical and mental. This profession was placed among the first places in work leave, due to temporary or permanent incapacity, accounting for about $30 \%$ of the causes of early abandonment of the profession. ${ }^{(11)}$

The Clinical Dysfunction Index (IDCCM or Helkimo Index) aims to classify volunteers into categories of severity of clinical signs of TMD. ${ }^{(14)}$

The mandibular functional impairment index (MFIQ) has a scoring system that makes it possible to classify severity categories of functional limitation related to TMD. One of its advantages is to measure the functional limitation related to TMD, differentiating it from other questionnaires that evaluate the severity of the signs and symptoms. ${ }^{(14,15)}$

There is a lack of studies related to the mandibular functional impairment in undergraduate students of Dentistry who presented TMD, although there are a large number of studies that relate TMD in this public. It is also known that there is a high number of absences, absenteeism at work due to pain, stress or discomfort caused by mandibular functional impairment and TMD.

So, it is noted the importance of studies aimed at a premature orientation, initiated in academic life, in the search for the promotion of preventive measures for postural disorders and TMD in dentists, thus, the objectives of this study are to classify TMD, to identify mandibular functional impairment and the main complaint related to TMD in undergraduate students in Dentistry, since the limitation of mandibular functionality is one of the main symptoms of TMD.

\section{METHODS}

This was a transversal, practical, exploratory with a quantitative approach, epidemiological study. A total of 43 students were enrolled in the supervised internship course for the $8^{\text {th }}$ period, in the second semester of 2015, but only 24 students participated in the study, the other students did not want to participate in the study or were not present at the time of the collection.

Students of the undergraduate course in Dentistry of the "Centro Universitário do Triângulo-UNITRI" were included in the research, who were enrolled in the supervised internship of the $8^{\text {th }}$ period, in the second semester of 2015, and were present at the time of data collection, without discrimination of gender, age or ethnicity, with or without chronic pain followed by prolonged periods, crepitus, joint stiffness in TMJ or any other symptom that is related to mandibular functional impairment. All of them agreed to voluntarily participate in the study without financial benefit.

The students excluded were: those who were not enrolled in the internship of the $8^{\text {th }}$ period, in the second semester of 2015, who were in the treatment of TMD, who were diagnosed with anterior displacement of the TMJ disc through image examination (Magnetic Resonance Imaging), who presented acute TMJ pain within 3 months before the interview, who had clinical diagnosis or retrodiscite exams, who did not spontaneously agree to participate in the research and those students who were not present at the time of data collection.

Data collection was performed using two questionnaires: Helkimo Index or Clinical Dysfunction Index (IDCCM) and the mandibular functional impairment index questionnaire (MFIQ). Also a sample characterization was performed.

In order to evaluate the degree of TMD of the participants, the Helkimo Index was used, which was subdivided into five items: Limitation of mandibular range of motion, measured 
through a $70 \%$ alcohol-sterilized stainless steel pachymeter, measuring the buccal opening between the upper and lower central incisors and the lateral movement, in which the evaluated participant was in the position of Frankfurt, that consists of the natural position of the head, correct posture of the body and alignment with the cervical spine, determined by the balance of the head and body when the individual looks forward. Also in this same position, the limitation of the TMJ function was evaluated through the auscultation with the Littmann stethoscope, and the palpation of the joint was performed, along with this, observing whether existed the presence of pain in the TMJ function or in the mandibular movement. The sensitivity to palpation of the extra and intraoral muscles was also evaluated, and at the time of palpation of the intraoral muscles were used disposable latex gloves (Descarpack).

In a second moment, a sample characterization was performed, consisting of 10 questions about three domains (complaints related to the mandible, pain near the TMJ and possible difficulty eating certain foods). After this the participants were invited to answer the MFIQ, composed of 17 questions involving independent variables (gender and age) and dependent variables (relate the complaints about their jaw regarding the difficulty in performing: speech, eating, working and/or performing your daily activities, laughing, yawning and kissing).

All students participating in the research were evaluated by a single researcher who rigorously followed the chosen methodology. Before the questionnaire was applied the students were clarified about the application and the purpose of the research and signed the consent form. The questionnaire was answered by the volunteers and applied without time control, so that the student could answer completely and correctly.

The research followed the legal ethical aspects and the project ( $n$ - 1.198.160) was approved by the Research Ethics Committee of the "Centro Universitário do Triângulo-UNITRI", in Uberlândia, MG, Brazil.

\section{RESULTS}

Twenty-four volunteers participated in this study, being 7 males (29.17\%) and 17 females (70.83\%), which reflects a greater participation of women. The mean age was 23.9 years and the standard deviation was 3 years and 8 months.

All participants had some degree of TMD, figure 1 represents the percentage of it, and $16.67 \%(04)$ of the students showed mild dysfunction, $70.83 \%$ (17) of them showed moderate dysfunction and $12.50 \%$ (03) showed severe dysfunction.

The figure 2 shows the percentages of patients, in relation to the variation of the results obtained by the Helkimo Index, according to gender, in which $5.88 \%(01)$ of the females presented mild TMD, $82.36 \%$ (14) moderate TMD and $11.76 \%$
(02) severe TMD. As for males, 42.86\% (03) presented mild TMD $42.86 \%$ (03) moderate TMD and $14.28 \%$ (01) severe TMD.

In relation to the results obtained through the MFIQ, 15 (62.50\%) presented C Index of 0 and only 03 (12.50\%) presented C Index of 0.01 . The others obtained C Index between 0.04 and 0.14 . However, all participants presented a $\mathrm{C}$ Index lower than 1 , in this way all were classified as having a low degree of severity.

In order to verify the existence of statistically significant correlations, between the values of variation of the limitations and the values of variation of the dysfunction, the Spearman Correlation Coefficient was applied. ${ }^{(16)}$

The level of significance was established in 0.05 in a bilateral test. The $r$ value found was 0.3919 and the probability associated with it was $p=0.058$. This indicates that there was no statistically significant correlation between the analyzed variables.

When asked if they felt pain in the neck and/or shoulders $45.83 \%$ (11) of the respondents said they had mild to moderate pain. The others $54.17 \%$ (13) related no pain in this area.

\section{DISCUSSION}

Temporomandibular dysfunction encompasses a group of musculoskeletal and neuromuscular conditions involving the temporomandibular joints, masticatory muscles and all associated tissues. ${ }^{(17)}$ Dentists have a risk factor for TMD, since during the visits, both head and body posture is not adequate. According to Viana et al. the posture of the head interferes with the posture of the mandible and the opposite can also happen, agreeing with Souza, who says that individuals with TMD present postural changes, mainly in head posture. ${ }^{(7,18)}$

The TMD can affect individuals of different age groups, Pedrotti, et al. report that the highest prevalence of TMD is between 20 and 45 years and Kinote et al. say that there is a predominance in the age group of 21 to 40 years, which corroborates with the results of the present study, which the students presented age between 20 and 38 years, with average age of 23,9 years and all presented some degree of severity of TMD. ${ }^{(19,20)}$

The results found in the present study show a higher prevalence of moderate TMD (70.83\%), followed by mild TMD (16.67\%) and severe TMD (12.50\%). In a study on the prevalence of TMD and association with parafunctional habits in students of Physiotherapy course of the "Universidade de Fortaleza", Queiroz et al., verified that most of the individuals presented mild TMD (53\%), followed by moderate TMD (27\%), severe TMD (10\%) and some of them did not present any degree of TMD (10\%). Parente et al. found higher values in the prevalence of mild TMD (37.37\%), lower in moderate TMD (35.16\%) and severe TMD (19.78\%), and others (7.69\%) did not presented TMD. The results obtained by Queiroz et al. and Parente et al., are in agreement with the results of the present study regarding the prevalence of moderate and mild TMD and in patients who did not present TMD, but 


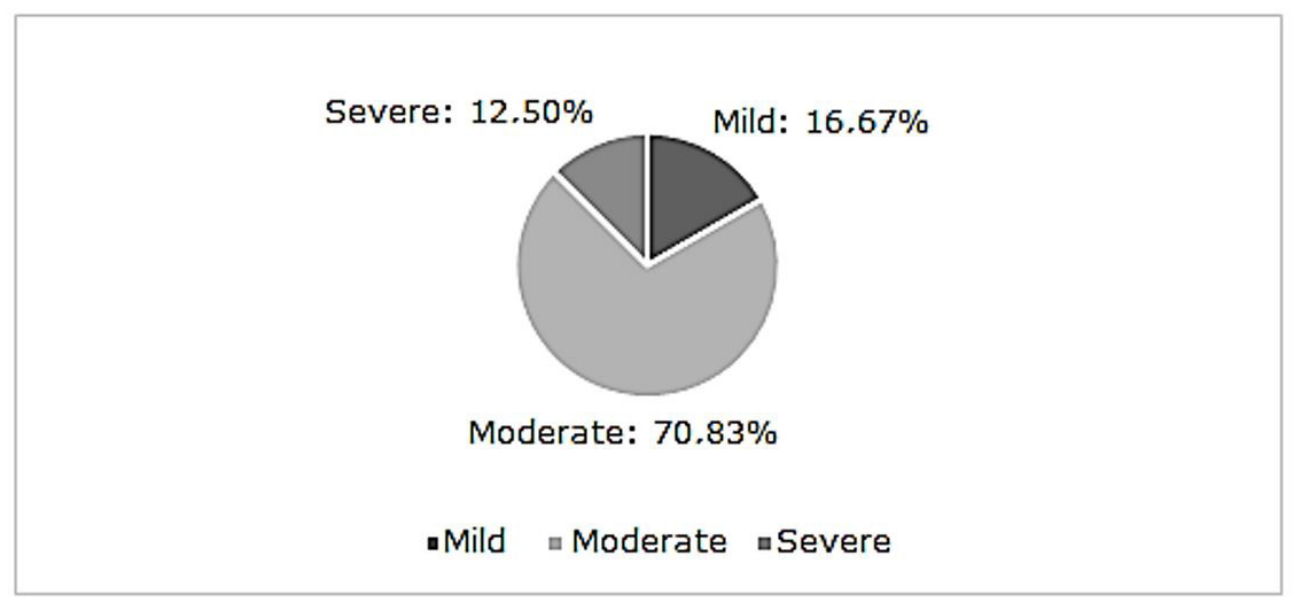

Figure 1. Classification of dysfunction according to the Helkimo Index.

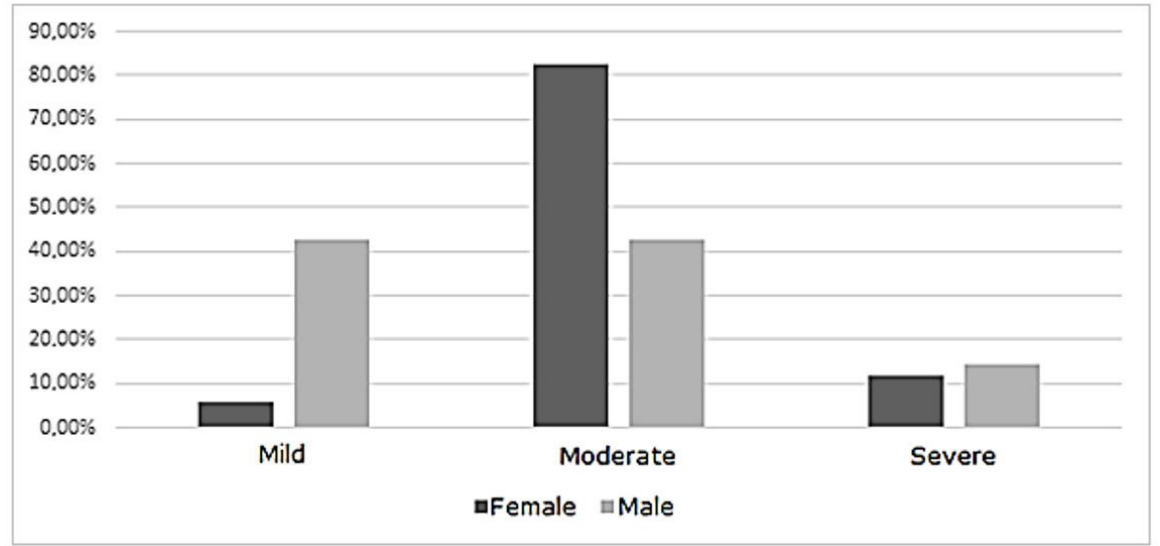

Figure 2. Percentage of patients, with regard to the variation of dysfunction, according to gender.

when it comes to severe TMD the results do not corroborate with the results of the present study, but were close. However Pedrotti et al. in their research on the diagnosis and prevalence of temporomandibular disorders in undergraduate students of the Dentistry course in the ULBRA Canoas/RS, found that $29,69 \%$ of the individuals presented mild TMD, $61,1 \%$ moderate TMD, 8,9\% severe TMD and 0,4\% did not presented TMD, corroborating with this study. ${ }^{(19,21,22)}$

Individuals with TMD can be studied through characteristic signs and symptoms. ${ }^{(17)}$ According to Bassi et al. and Pachioni et al. the mandibular functional impairment is one of the main symptoms of TMD, being used even through the MFIQ as a parameter to follow treatment evolution of patients with TMD. ${ }^{(1,3,14)}$ Viana et al. observed that $56.5 \%$ presented difficulty to open the mouth, $39.1 \%$ difficulty to close the mouth, $78.3 \%$ difficulty to chew e $73.9 \%$ difficulty to yawning. ${ }^{(18)}$ Portinho et al. found that $53.7 \%$ presented crackling and $22,2 \%$ presented articular instability, which constitutes the mandibular functional impairment. ${ }^{(24)}$ However, the results found in the present research contradict the results of the other authors, since all the participants had a low functional limitation index even presenting TMD and did not present symptoms of the it.

When the correlation analysis was performed between TMD and mandibular functional impairment, the value of $p$ found was 0.058 indicating that there was no statistically significant correlation between the values of the variables analyzed, in which the level of relevance established was 0.05 .

As for the presence of pain in the neck and/or shoulders, 11 individuals presented pain (45.83\%). Goyatá et al. ${ }^{(23)}$ found that $32,9 \%$ of the evaluated patients presented head and neck pain, presenting a value close to the one of this study. However Portinho et al. ${ }^{(24)}$ in their study on the Profile of Patients with Temporomandibular Dysfunction, showed that $22,2 \%$ of the evaluated showed cervicalgia, presenting lower values than those found in our study. Scopel and Oliveira(25) found that $71,8 \%$ of the evaluated had neck pain and $41 \%$ had shoulder pain. Viana et al. showed that $78,3 \%$ of the evaluated presented muscle pain close to the TMJ, so both Scopel and Oliveira and Viana et al., presented higher values than in this study, presenting greater involvement in the region of neck and shoulders. ${ }^{(18,25)}$ 


\section{CONCLUSION}

The results of this research showed a high prevalence of moderate TMD in dentistry students and there is no correlation between TMD and mandibular functional impairment. It was observed that many students had pain in the neck and/or shoulder.

\section{AUTHORS' CONTRIBUTIONS:}

All the authors worked actively for the article, participating in all the phases. This article is linked to the Doctoral Project in Dentistry - FOUFU of the EAG, doctoral student. The TTG participated as an undergraduate student and did the completion of coursework from this article. The Master Professor KDLM was advisor in the completion of coursework of the student. The PhD Professors PCSJ, GCSA and AJFN are advisors of the EAG. The whole group works cohesively and dynamically.

\section{CONFLICT OF INTEREST:}

There was no conflict of interest

\section{AUTHOR DETAILS}

${ }^{2}$ Physiotherapist, Centro Universitário do Triangulo (Unitri) , Uberlândia (MG), Brazil.

${ }^{3}$ Physiotherapist, Professor, Centro Universitário do Triangulo (Unitri), Uberlândia (MG), Brazil.

${ }^{4}$ Physiotherapist, Master in Health Science, Universidade Federal de Uberlândia (UFU), Uberlândia (MG), Brazil.

${ }^{5}$ Professor, Faculdade de Odontologia, Universidade Federal de Uberlândia (UFU), Uberlândia (MG), Brazil.

${ }^{6}$ Professor, Instituto de Ciências Biomédicas, Universidade Federal de Uberlândia (UFU), Uberlândia (MG), Brazil.

\section{REFERENCES}

1 - Bassi AFB, Morimoto RS, Costa ACS. Disfunção temporomandibular: uma abordagem fisioterapêutica. In: Encontro científico e simpósio de educação UNISALESIANO, 3, 2011. Anais ... Lins: Disponível em < http:// www.unisalesiano.edu.br/simposio2011/publicado/artigo0089.pdf.>. Acesso em: 26 fev. 2015.

2 - Schaefer D. Correlação entre desordem temporomandibular e postura corporal. 63f. Monografia (Trabalho de Conclusão de Curso em Odontologia) Florianópolis, SC, 2014. Disponível em < https://repositorio. ufsc.br/xmlui/handle/123456789/127290.>. Acesso em: 03 mar. 2015.

3 - Pachioni CAS, Flecha OD, de Oliveira Filho PM. Análise de condições clínicas em estudantes com disfunção temporomandibular. Association Posturologie Internationale. 2013;11(53):361-366.

4 - Maydana AV, Tesch RS, Denardin OVP, Ursi WJS, Dworkin SF. Possíveis fatores etiológicos para desordens temporomandibulares de origem articular com implicações para diagnóstico e tratamento. Dental Press J Orthod. 2010;15(3):78-86.

5 - Watanabe SK. Diagnóstico da disfunção tempromandibular. Revista Ciência em Saúde. 2014;4(1):2-6.

6 - Aoyama AY, et al. Disfunção temporomandibular e sua relação com a postura. Colloquium Vitae. 2011;3(esp):270-276

7 - Souza J. Postura e disfunção temporomandibular: avaliação fotogramétrica, barapodométrica e eletromiográfica. 130 f. Dissertação (Mestrado em Distúrbios da Comunicação Humana). Santa Maria - RS, 2010. Disponível em < http://cascavel.ufsm.br/tede/tde_arquivos/26/TDE-2010-0709T114230Z-2703/Publico/SOUZA,\%20JULIANA\%20ALVES.pdf.>. Acesso em: 28 fev. 2015

8 - Zenker JEA, et al. Sistema estomatognático, postura e equilíbrio corporal. Salusvita. 2010;29(2):57-67.
9 - Faulin EF. Análise da prevalência de disfunção têmporomandibular e alteração de postura de cabeça em estudantes de odontologia da Universidade de Brasília. 46 f. Dissertação (Mestrado em Ciências da Saúde). Brasília - DF, 2010. Disponível em < http://hdl.handle. net/10482/7149 http://hdl.handle.net/10482/7149.>. Acesso em: 17 fev. 2015.

10 - Salvatti SC. Terapia manual integrada e reeducação funcional dos distúrbios temporomandibulares de origem muscular. 72 f. Monografia (Trabalho de Conclusão de Curso em Fisioterapia). Criciúma- SC: UNESC, 2011. Disponível em < http://repositorio.unesc.net/handle/1/342.>. Acesso em: 17 fev. 2015.

11 - Siqueira GR, Vieira RAG, Silva AM, Silva RB. Dores músculo-esqueléticas em estudantes de odontologia. Revista brasileira em promoção da saúde. 2010;16(2):150-159.

12 - Ferreira FB, da Cruz LMP, Urban VM, Fernandes F, Campanha NH, Jorge $\mathrm{JH}$. Prevalência das desordens temporomandibulares em graduandos da Universidade Estadual de Ponta Grossa. Arquivos em Odontologia. 2012;48(1):13-18.

13 - Carneiro P. Análise ergonómica da postura e dos movimentos na profissão de médico dentista. 120 f. Dissertação (Mestrado em Engenharia Humana). Braga - Portugal, 2005. Disponível em < http://hdl.handle. net/1822/960.>. Acesso em: 19 fev. 2015.

14 - Chaves TC, Oliveira AS, Grossi DB. Principais instrumentos para avaliação da disfunção temporomandibular, parte I: índices e questionários; uma contribuição para a prática clínica e de pesquisa. Fisioterapia e Pesquisa. 2007;15(1):92-100.

15 - da Costa LMR, de Medeiros DL, Ries LGK, Beretta A, de Noronha MA. Avaliação das adaptações transculturais e propriedades de medida de questionários em língua portuguesa relacionados às desordens temporomandibulares: uma revisão sistemática. Fisioterapia e Pesquisa. 2014;21(2):107-112.

16 - Siegel S. Estatística não-paramétrica, para as ciências do comportamento". Trad. Alfredo Alves de Farias. Ed. McGraw-Hill do Brasil. São Paulo, 1975. 350 p. 1975.

17 - Machado MB, Nitsch GS, Pitta NC, Oliveira AS. Tempo de ativação muscular em portadoras de disfunção temporomandibular durante a mastigação. Audiol., Commun. Res. [Internet]. 2014;19(2):202-207.

18 - Viana MO, Lima EICBMF, Menezes JNR, Olegario NBC. Avaliação de sinais e sintomas da disfunção temporomandibular e sua relação com a postura cervical. Rev. odontol. UNESP [Internet]. 2015;44(3):125-130.

19 - Pedrotti F, Mahl C, Freitas MPM, Klein G. Diagnóstico e prevalência das disfunções temporomandibulares em graduandos do curso de Odontologia da ULBRA Canoas/RS. Stomatos. 2011;17(32):15-23.

20 - Kinote APBM, Monteiro LT, Vieira AAC, Ferreira NMN, Abdon APV. Perfil funcional de pacientes com disfunção temporomandibular em tratamento fisioterápico. Revista brasileira em promoção da saúde. 2011;24(4):306312.

21 - Queiroz NBD, Magalhães Km, Machado J, Viana Mo. Prevalência de disfunção temporomandibular e associação com hábitos parafuncionais em alunos do curso de Fisioterapia da Universidade de Fortaleza. Revista rede de cuidados em saúde. 2015;9(1):1-14.

22 - Parente IA, Cerdeira DQ. Disfunção temporomandibular a avaliação fisioterapêutica em discentes de uma instituição de ensino superior do município de sobral-ceará. SANARE-Revista de Políticas Públicas. 2013;12(2):27-33.

23 - Goyata FR, et al. Avaliação de sinais e sintomas de disfunção temporomandibulares entre os acadêmicos do curso de Odontologia da Universidade Severino Sombra, Vassouras-RJ. Revista de Odontologia. 2010;9(4):181-186.

24 - Portinho CP, Collares Mvm, Faller Gj, Fraga Mm, Pinto Ra. Perfil dos pacientes com disfunção temporomandibular. Arquivos Catarinenses de Medicina. 2012;41(1):95-99.

25 - Scopel J, Oliveira PAB. Prevalência de sintomas osteomusculares, postura e sobrecarga no trabalho em cirurgiões-dentistas. Revista brasileira de medicina do trabalho. 2011;9(1):26-32. 